\title{
Peningkatan Perkembangan Bahasa Melalui Metode Membaca Pada Permainan Kartu Kata di RA Al Huda Penulupan Pohjentrek Pasuruan
}

\author{
Nur Hidayati ${ }^{1,}$ Yuli Ani Setyo Dewi ${ }^{2}$ \\ ${ }^{12}$ STITNU Al Hikmah Mojokerto \\ yulianisetyo85@gmail.com
}

\begin{abstract}
Abstrak : Penelitian ini bertujuan untuk mengetahui pelaksanaan pembelajaran menggunakan media kartu kata dalam meningkatkan kemampuan bahasa anak melalui metode membaca. Metode yang digunakan adalah metode penelitian tindakan kelas terhadap siswa kelompok B di RA Al Huda Penulupan Kecamatan Pohjentrek dengan jumlah siswa 24 anak yang terdiri dari 11 Putri dan 13 Putra. Teknik pengumpulan data menggunakan observasi dan dokumentasi. Analisis data menggunakan teknik kualitatif. Hasil penelitian menunjukkan bahwa penggunaan media kartu kata pada pembelajaran anak RA B dapat membantu meningkatkan perkembangan kemampuan bahasa dengan metode membaca dengan media permainan kartu kata lebih baik dari pada anak yang belajar dengan pembelajaran konvensional. Hal ini dikarenakan belajar dengan menggunakan media kartu kata lebih mengefektifkan komunikasi dan interaksi guru dengan siswa dalam proses perkembangan bahasa anak.
\end{abstract}

Kata Kunci: Kartu Kata, Perkembangan Bahasa, Metode Membaca

PENDAHULUAN

Rodhotul Athfal (RA) merupakan salah satu lembaga tempat pendidikan anak usia dini yang berada pada jalur formal, di mana pada usia ini merupakan masa keemasan (golden age) khususnya usia 5-6 tahun, dengan adanya RA bertujuan membantu mengembangkan potensi yang dimiliki oleh anak antara lain nilai-nilai agama dan moral, sosial, emosional, kognitif, bahasa, fisik motorik, dan juga kemandirian, maka dari itu pengembangan potensi yang dimiliki oleh anak tersebut hendaknya dilaksanakan dengan berbagai metode kegiatan belajar yang kreatif dan menyenangkan bagi anak didik.

Pada fase masa keemasan (golden age) inilah peran pendidikan sangat fundamental dan sangat menentukan perkembangan anak selanjutnya. Apabila anak 
mendapatkan stimulus yang baik, maka seluruh aspek perkembangan anak akan berkembang secara optimal. Oleh karena itu pendidikan anak usia dini harus dapat merangsang seluruh aspek perkembangan anak baik perkembangan perilaku, bahasa, kognitif, sosial emosional, kemandirian maupun fisik motorik.

Pertumbuhan dan perkembangan pada anak usia dini ini merupakan periode yang sangat penting karena pada masa ini pertumbuhan dasar yang akan mempengaruhi dan menentukan perkembangan anak selanjutnya. Perkembangan pada usia dini meliputi perkembangan kemampuan berbahasa, kreatifitas kesadaran sosial, emosional dan intelegensia berjalan sangat cepat dan merupakan landasan perkembangan berikutnya. Perkembangan moral serta dasar-dasar kepribadian juga dibentuk pada masa tersebut. Perkembangan ini terdapat masa kritis, dimana diperlukan rangsangan/stimulasi yang berguna agar potensi berkembang.

Manusia dalam kehidupannya tidak terlepas dengan bahasa. Ia harus mampu menggunakan bahasa sebagai alat komunikasi. Dengan bahasa, mereka akan mudah dalam bergaul dan mudah menyesuaikan diri dengan lingkungannya. Bahasa mempunyai peranan yang sangat penting bagi kehidupan manusia (Suhartono, 2005:12). Dengan demikian perkembangan bahasa harus dirangsang sejak dini.

Kemampuan berbahasa anak merupakan suatu hal yang penting karena dengan bahasa tersebut anak dapat berkomunikasi dengan teman atau orang orang disekitarnya. Bahasa merupakan bentuk utama dalam mengekspresikan pikiran dan pengetahuan bila anak mengadakan hubungan dengan orang lain. Bahasa juga suatu simbol atau lambang yang digunakan untuk menyampaikan keinginan/pikiran dan berkomunikasi dengan orang lain baik berupa verbal maupun visual (Dewi, 2017a). Anak yang sedang tumbuh dan berkembang mengkomunikasikan kebutuhan, pikiran dan perasaannya melalui bahasa dengan kata-kata yang mempuyai makna. 
Kemampuan berbahasa pada anak usia 4-6 tahun berdasarkan PERMENDIKNAS no 58 tahun 2009 tanggal 17 september 2009 tentang standar tingkat pencapaian perkembangan bahasa anak meliputi: 1) menerima bahasa. Tingkat pencapaian perkembangan yang diharapkan adalah: menyimak perkataan orang lain, mengerti beberapa perintah secara bersamaan, memahami cerita yang dibacakan, mengenal perbendahaan kata mengenai kata sifat, mengulang kalimat yang lebih kompleks, memahami aturan dalan suatu permainan; 2) mengungkapkan bahasa. Tingkat pencapaian perkembangan meliputi: mengulang kalimat sederhana, menjawab pertanyaan secara sederhana, menyebutkan kata-kata yang dikenal, menceritakan kembali cerita atau dongeng yang pernah didengar, berkomunikasi secara lisan serta mengenal simbol-simbol untuk persiapan membaca, menulis dan berhitung; dan 3) keaksaraan. Tingkat pencapaian perkembangan yang diharapkan meliputi: mengenal suara-suara atau benda yang ada di sekitarnya, membuat coretan yang bermakna, meniru huruf, memahami hubungan bunyi dan bentuk huruf, membaca dan menulis nama sendiri. Melalui pembelajaran di Taman Kanak-kanak diharapkan mampu mengembangkan aspek-aspek perkembangan anak sesuai dengan kurikulum Taman Kanak-kanak tahun 2010 yaitu : 1). Nilai-nilai agama dan moral, 2).Fisik, 3). Kognitif, 4). Bahasa.

Salah satu komponen berbahasa adalah membaca. Mengajarkan membaca di Taman Kanak-kanak dapat dilaksanakan selama dalam batas-batas aturan pengembangan pra-skolatik atau pra akademik serta mendasarkan diri pada prinsip dasar hakiki dari pendidikan Taman Kanak-kanak sebagai sebuah taman bermain (dalam depdiknas, 2000:2).

Beberapa pakar membaca bahkan menyebutkan bahwa pengajaran membaca sudah dapat diberikan ketika seseorang masih dalam kandungan. 
Mengingat urgensi dari kegiatan membaca tersebut, maka kegiatan membaca harus diberikan kepada anak sejak masih dalam pengasuhan kedua orang tua. Kedua orang tua adalah pendidik pertama yang menanamkan dasar bagi perkembangan jiwa anak. Anak adalah peniru yang peka. Sikap hidup dan kebiasaan anak sehari-hari adalah peniru dari orang tua yang akan mempengaruhi perkembangan pribadinya. Kewajiban orang tua tidak hanya sebagai seorang pribadi tetapi juga memberikan pendidikan yang sesuai (Crow, $1994: 95)$.

Bermula dari latar belakang tersebut di atas, maka peneliti ingin memperbaiki proses pengenalan bahasa anak dengan cara melakukan penelitian dengan judul : "Peningkatan Perkembangan Bahasa Melalui Metode Membaca Pada Permainan Kartu Kata Di Kelompok B RA AL HUDA Penulupan Parasrejo Pohjentrek Pasuruan Tahun Ajaran 2017/2018."

Bahasa mempunyai beberapa pengertian. Menurut Oxford Advanced Learner Dictionary bahasa adalah suatu sistim dari suara, kata, pola yang digunakan oleh manusia untuk berkomunikasi melalui pikiran dan perasaan. Sedangkan menurut pandangan Hurlock (1978: 176) bahasa adalah sarana komunikasi dengan menyimbolkan pikiran dan perasaan untuk menyampaikan makna kepada orang lain. Syamsu Yusuf (2007: 118) mengatakan bahwa bahasa adalah sarana berkomunikasi dengan orang lain. Dalam pengertian ini tercakup semua cara untuk berkomunikasi, dimana pikiran dan perasaan dinyatakan dalam bentuk lambang atau simbol untuk mengungkapkan suatu pengertian.

Dari hasil penelitian yang telah dilakukan (Dewi, 2017b) banyak stimulasi yang digunakan oleh para guru agar perkembangan bahasa siswanya bisa berkembang secara maksimal yaitu diantaranya mengajak mereka berdialog dan berkomunikasi baik di dalam maupun di luar kelas. Karena dengan sering mengajak anak berbibacara maka mereka akan lebih cepat dan berani untuk berbicara. 
Tahapan Membaca Anak Usia Dini

Tahapan membaca menurut Mortimer J.Adler dan Charles Van Doren (2007: 28-31), dibagi dalam 4 tahap yang meliputi:

1. Kesiapan membaca, yaitu berhubungan dengan pengalaman membaca pada tingkat prasekolah. Tahap ini dimulai sejak lahir, dan biasanya berlanjut sampai sekitar usia enam atau tujuh tahun.

2. Penguasaan kata, yaitu berhubungan dengan pengalaman membaca kelas 1 SD. Hasilnya, anak menguasai apa yang disebut keterampilan membaca tahap kedua atau kemampuan membaca kelas satu.

3. Pertambahan penguasaan kosa kata dan penggunaan konteks, yaitu secara umum terjadi pada kelas $4 \mathrm{SD}$, dan menghasilkan apa yang disebut kemampuan membaca fungsional, mampu membaca rambu-rambu lalu lintas atau petunjuk-petunjuk dengan cukup lancar, mengisi formulir yang sederhana, dan sejenisnya.

4. Tahap literasi kelas 8,9 , atau 10 , pada tahap ini anak bisa menjadi pembaca dewasa, anak bisa membaca hampir semua materi yang relatif sederhana. Singkatnya, anak cukup dewasa untuk tugas membaca di SMA.

Pada penelitian ini, tahapan membaca yang digunakan adalah tahap membaca kata. Selain itu, dikarenakan obyek yang diteliti adalah anak di RA atau masih dalam usia prasekolah maka termasuk dalam tahapan kesiapan membaca. Kesiapan membaca meliputi berbagai kesiapan belajar, kesiapan fisik meliputi penglihatan dan pendengaran yang baik, kesiapan intelektual meliputi tingkat persepsi visual minimum anak bisa menyerap dan mengingat kata-kata dan huruf pembentuknya. 
Kartu kata merupakan salah satu bentuk alat permainan edukatif (APE), yang menggunakan media kartu. Menurut Suharso dan Ana Retnoningsih (2009: 226), Kartu adalah kertas tebal yang berbentuk persegi panjang, untuk keperluan seperti: tanda anggota, karcis dan lain-lain. Media kartu adalah adalah kartu kecil yang berisi gambar, konsep, soal, atau tanda simbol yang mengingatkan atau menuntun anak kepada sesuatu yang berhubungan dengan materi yang sedang dipelajari. Kartu tersebut biasanya berukuran $8 \times 12 \mathrm{~cm}$ atau dapat disesuaikan dengan besar kecilnya yang dihadapi (Azhar Arsyad, 2006: 119).

Hasil dari penelitian yang dilakukan oleh (Dewi, 2014) menunjukkann bahwa salah satu penghambat guru dalam pembelajaran adalah kurangnya media pembelajaran yang dimiliki oleh sekolah. Materi/tema yang dipelajari dalam penelitian ini disesuaikan dengan tema pembelajaran. Media kartu kata ini terbuat dari kertas berukuran $12 \mathrm{~cm} \times 12 \mathrm{~cm}$, yang masing-masing kartu yang berisi kata dan gambar yang ditulis dengan huruf yang mencolok dengan warna yang menarik.

\section{METODE PENELITIAN}

Rancangan penelitian merupakan perencanaan atau strategi yang digunakan untuk mengatur latar penelitian agar penelitian memperoleh data yang valid sesuai dengan tujuan peelitian yang diinginkan. Bentuk penelitian yang digunakan dalam penelitian ini adalah Penelitian Tindakan Kelas (Classroom Action Research) yang berawal dari permasalahan yang dijumpai dilapangan yang kemudian direfleksikan dan selanjutnya diadakan tindakan. Rencana Penelitian Tindakan Kelas (PTK) dlam penelitian ini menggunakan beberapa siklus. Menurut Arikunto (2008:16) desain penelitian menggunakan empat tahapan, yaitu : Perencanaan (Planning), Tindakan (Acting), Observasi (Observation), dan Refleksi (Reflection). 
Bentuk-bentuk instrumen adalah sebagai berikut: 1) angket, 2) checklist, dan 3) rating scale. Bentuk checklist dan rating scale dapat digunakan sebagai pedoman observasi maupun wawancara (Sugiyono, 2010: 172).

Disini peneliti telah menentukan indikator dan sub indikator berdasarkan variabel yang akan di teliti dengan menggunakan skala likert penelitian dan memberikan bobot atau di samakan dengan nilai kuantitatif 4 (mampu), 3 (cukup mampu), 2 (belum mampu), 1 (kurang mampu).

Kisi-kisi instrumen yang digunakan untuk mencapai indikator keberhasilan dalam penelitian ini adalah sebagai berikut:

Tabel 1

Daftar Skala Penelitian Diskriptif

Dalam Meningkatkan Kemampuan Bahasa Anak Melalui Metode Membaca dengan Media Kartu Kata.

\begin{tabular}{|l|l|l|l|l|}
\hline \multicolumn{1}{|c|}{ Aspek yang diobservasi } & \multicolumn{3}{c|}{ Peneliaian } \\
\cline { 2 - 5 } & 1 & 2 & 3 & 4 \\
\hline Berbicara & & & & \\
\hline $\begin{array}{l}\text { Menjawab pertanyaan yang lebih } \\
\text { kompleks misal: “ apa yang harus } \\
\text { kita lakukan sebelum berangkat } \\
\text { sekolah...?" }\end{array}$ & & & & \\
\hline $\begin{array}{l}\text { Menceritakan kejadian sebab-akibat } \\
\text { misal: “adanya hujan, banjir, pelangi, } \\
\text { gempa bumi... dst" }\end{array}$ & & & & \\
\hline $\begin{array}{l}\text { Menyebutkan sebanyak- } \\
\text { banyaknya nama benda yang ada } \\
\text { di sekitarnya misal: " meja, kursi, } \\
\text { buku, pensil, tas dst..." }\end{array}$ & & & & \\
\hline $\begin{array}{l}\text { Membaca } \\
\text { Menyebutkan simbol-simbol huruf } \\
\text { yang dikenal misal: " A-B-C-D......dst }\end{array}$ & & & & \\
\hline $\begin{array}{l}\text { Mengenal suku huruf awal dari } \\
\text { nama benda-benda yang ada } \\
\text { disekitarnya, seperti: gelas, piring, } \\
\text { sendok, susu, sayur, nasi,. }\end{array}$ & & & & \\
\hline
\end{tabular}




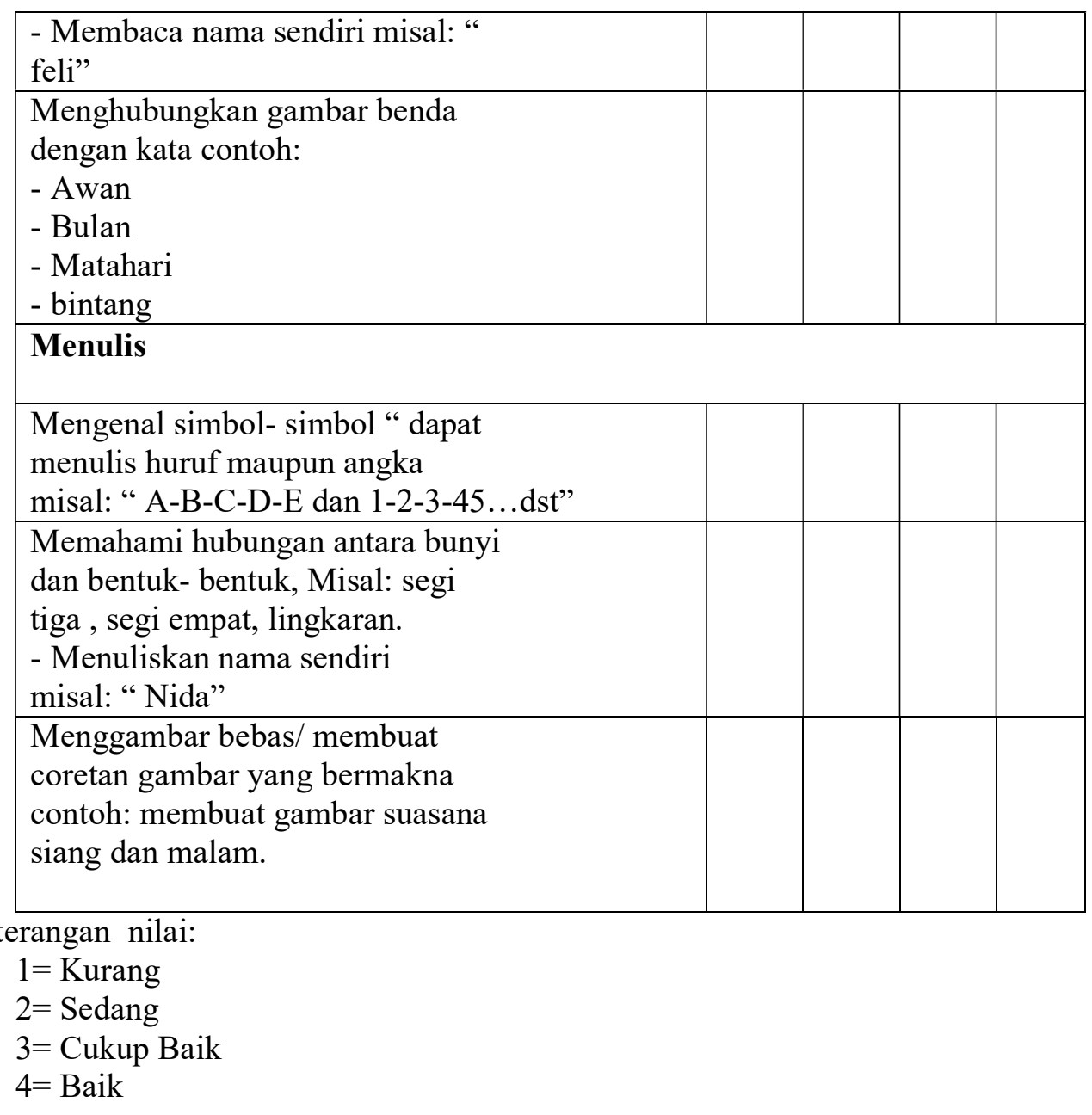

Dilakukan setelah semua data terkumpul, proses analisa data dimulai dengan menelaah data angka yang tersedia dari berbagai sumber, selanjutnya menyusun data angka tersebut menjadi kalimat dan kata-kata yang bermakna dan ilmiah.

Teknik pengumpulan data pada penelitian ini diuraikan sebagai berikut :

1. Data tentang situasi pembelajaran pada saat dilaksanakan pembelajaran dikumpulkan dengan menggunakan lembar pengamat observasi pada setiap siklus

2. Dokumentasi aktivitas siswa (foto menggunakan kamera HP) diambil pada setiap siklus. 
Analisis data adalah suatu cara menganalisis data selama peneliti mengadakan penelitian. Penelitian ini termasuk penelitian kuantitatif dan kualitatif.Secara kuantitatif data yang terkumpul dianalisa secara deskriptif presentase. Tingkat perubahan yang terjadi diukur dengan persen. Jumlah anak yang mampu mencapai indikator keberhasilan dibagi jumlah seluruh anak yang diteliti dikalikan seratus persen, maka diketahui persentase dari tingkat keberhasilan tindakan. Hal tersebut dapat diketahui dengan rumus :

$$
\begin{aligned}
& \mathrm{P}=\frac{N}{A} \times 100 \% \\
& \text { Keterangan : } \\
& \mathrm{P}=\text { Presentase tingkat perubahan } \\
& \mathrm{N}=\text { Nilai yang diperoleh } \\
& \mathrm{A}=\text { Jumlah anak }
\end{aligned}
$$

Sedangkan secara kualitatif menerangkan aktifitas anak dan guru yang diperoleh melalui observasi, wawancara dan unjuk kerja secara penelitian berlangsung.

\section{HASIL}

1. Hasil penelitian sebelum di beri tindakan

Hasil penelitian perkembangan bahasa anak didik diperoleh dengan prosedur penelitian tindakan kelas melalui pembelajaran dengan metode membaca dengan bantuan media kartu kata dalam upaya meningkatkan perkembangan bahasa anak didik kelompok B RA Al Huda Penulupan Desa Parasrejo Kecamatan Pohjentrek kabupaten Pasuruan dapat di deskripsikan sebagai berikut: 
Tabel 2

Data Hasil Pengamatan Peningkatan Kemampuan Bahasa

Dengan Menggunakan Metode Membaca Dengan Media

Kartu Kata Sebelum Diberikan Tindakan

Kelas B RA Al Huda Penelupan

\begin{tabular}{|c|c|c|c|c|c|c|c|}
\hline \multirow[t]{2}{*}{ karakteristik } & \multirow[t]{2}{*}{ Indikator } & \multicolumn{4}{|c|}{ Hasil pengamatan } & \multirow{2}{*}{$\begin{array}{l}\text { Jumlah } \\
\text { yang } \\
\text { tuntas }\end{array}$} & \multirow[t]{2}{*}{$\%$} \\
\hline & & 1 & 2 & 3 & 4 & & \\
\hline \multirow[t]{3}{*}{ Mendengar } & $\begin{array}{lr}\text { Mengerti } & \text { beberapa } \\
\text { perintah } & \text { secara } \\
\text { sederhana } & \\
\end{array}$ & 3 & 6 & 5 & 10 & 10 & $42 \%$ \\
\hline & $\begin{array}{l}\text { Mengulang kalimat } \\
\text { yang lebih komplek }\end{array}$ & 4 & 8 & - & 12 & 12 & $50 \%$ \\
\hline & $\begin{array}{l}\text { Menyebut beberapa } \\
\text { kata sifat }\end{array}$ & 5 & 5 & 3 & 11 & 11 & $46 \%$ \\
\hline \multirow[t]{3}{*}{ Berbicara } & $\begin{array}{l}\text { Menjawab } \\
\text { pertanyaan yang } \\
\text { lebih komplek }\end{array}$ & 1 & 7 & 2 & 14 & 14 & $59 \%$ \\
\hline & $\begin{array}{l}\text { Menceritakan } \\
\text { kejadian sebab } \\
\text { akiba }\end{array}$ & 3 & 6 & 5 & 10 & 10 & $42 \%$ \\
\hline & $\begin{array}{l}\text { Menyebutkan } \\
\text { sebanyak } \\
\text { banyaknya benda } \\
\text { yang ada disekitar }\end{array}$ & 3 & 6 & 3 & 12 & 12 & $50 \%$ \\
\hline \multirow[t]{4}{*}{ Membaca } & $\begin{array}{l}\text { Menyebutkan } \\
\text { simbol - simbol } \\
\text { huruf yang dikenal }\end{array}$ & 3 & 7 & 6 & 8 & 8 & $34 \%$ \\
\hline & $\begin{array}{l}\text { Mengenal suku } \\
\text { huruf } \\
\text { awal dari nama } \\
\text { benda-benda yang } \\
\text { ada disekitarnya }\end{array}$ & 2 & 1 & 9 & 12 & 12 & $50 \%$ \\
\hline & $\begin{array}{l}\text { Membaca nama } \\
\text { sendiri }\end{array}$ & 3 & 7 & 5 & 9 & 9 & $\begin{array}{l}37,5 \\
\%\end{array}$ \\
\hline & $\begin{array}{l}\text { Menghubungkan } \\
\text { gambar benda } \\
\text { dengan kata }\end{array}$ & 3 & 8 & 6 & 7 & 7 & $30 \%$ \\
\hline \multirow[t]{3}{*}{ Menulis } & $\begin{array}{l}\text { Mengenal simbol- } \\
\text { simbol " dapat } \\
\text { menulis huruf } \\
\text { maupun angka }\end{array}$ & 5 & 7 & 4 & 8 & 8 & $34 \%$ \\
\hline & $\begin{array}{l}\text { Memahami } \\
\text { hubungan antara } \\
\text { bunyi dan bentuk- } \\
\text { bentuk }\end{array}$ & 3 & 5 & 6 & 10 & 10 & $42 \%$ \\
\hline & $\begin{array}{l}\text { Menuliskan nama } \\
\text { Sendiri }\end{array}$ & & 2 & 9 & 13 & 13 & $55 \%$ \\
\hline
\end{tabular}




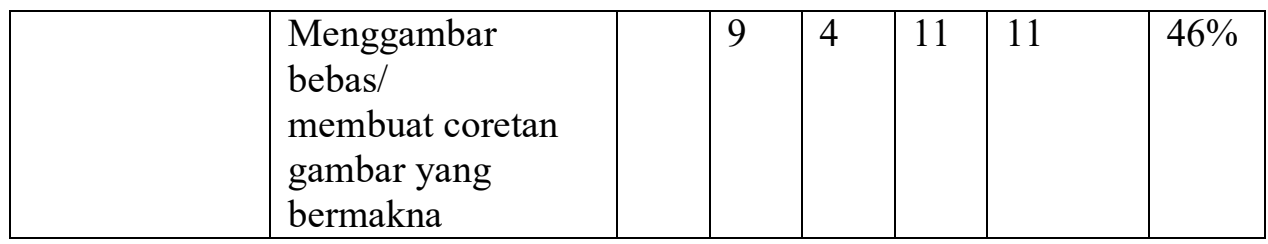

Kondisi ini sangat memprihatikan. Jika anak-anak dibiarkan begitu saja, maka hal ini akan sangat mempengaruhi perkembangan aspek lainya untuk selanjutnya. Salah satu bentuk tindakan yang bisa diberikan oleh guru/peneliti yaitu dengan menggunakan metode membaca dengan media kartu kata sebagai upaya meningkatkan kemampuan bahasa anak di kelompok B RA Al Huda Penulupan. Pengunaan metode tersebut dimaksudkan agar perkembangan bahasa anak dapat berkembang dengan baik

2) Hasil Observasi Siklus I

Observasi pada siklus I dilakukan secara kolaborasi dengan teman sejawat. Aspek yang diamati adalah kemampuan bahasa melalui membaca. Hasil observasi pada siklus I disajikan dalam tabel sebagai berikut:

Tabel 3

Data Hasil Pengamatan Peningkatan Kemampuan Bahasa Dengan Menggunakan Metode Membaca Dengan Media Kartu Kata Setelah Diberikan Tindakan pada Siklus I Kelas B RA Al Huda Penelupan

\begin{tabular}{|l|l|l|l|l|l|l|l|}
\hline Karakteristik & Indikator & \multicolumn{3}{|c|}{ Hasil Pengamatan } & \multicolumn{2}{l|}{$\begin{array}{l}\text { Jumlah } \\
\text { yang } \\
\text { tuntas }\end{array}$} & \% \\
\cline { 3 - 8 } & & $\mathbf{1}$ & $\mathbf{2}$ & $\mathbf{3}$ & $\mathbf{4}$ & & \\
\hline Mendengar & $\begin{array}{l}\text { Mengerti beberapa } \\
\text { perintah secara } \\
\text { sederhana }\end{array}$ & - & 2 & 7 & 15 & 15 & 62,5 \\
\hline & $\begin{array}{l}\text { Mengulang kalimat } \\
\text { yang lebih komplek }\end{array}$ & - & 1 & 7 & 16 & 16 & $67 \%$ \\
\hline & $\begin{array}{l}\text { Menyebut beberapa } \\
\text { kata sifat }\end{array}$ & - & - & 5 & 19 & 19 & $80 \%$ \\
\hline Berbicara & $\begin{array}{l}\text { Menjawab } \\
\text { pertanyaan yang }\end{array}$ & - & 1 & 10 & 13 & 13 & $55 \%$ \\
\hline
\end{tabular}




\begin{tabular}{|c|c|c|c|c|c|c|c|}
\hline & lebih komplek & & & & & & \\
\hline & $\begin{array}{l}\text { Menceritakan } \\
\text { kejadian sebab } \\
\text { akiba }\end{array}$ & - & 1 & 5 & 18 & 18 & $75 \%$ \\
\hline & $\begin{array}{l}\text { Menyebutkan } \\
\text { sebanyak } \\
\text { banyaknya benda } \\
\text { yang ada disekitar }\end{array}$ & - & - & 5 & 19 & 19 & $80 \%$ \\
\hline \multirow[t]{4}{*}{ Membaca } & $\begin{array}{l}\text { Menyebutkan } \\
\text { simbol - simbol } \\
\text { huruf yang dikenal }\end{array}$ & - & - & 5 & 19 & 19 & $80 \%$ \\
\hline & $\begin{array}{l}\text { Mengenal suku } \\
\text { huruf } \\
\text { awal dari nama } \\
\text { benda-benda yang } \\
\text { ada disekitarnya }\end{array}$ & - & 2 & 5 & 17 & 12 & $71 \%$ \\
\hline & $\begin{array}{l}\text { Membaca nama } \\
\text { sendiri }\end{array}$ & - & 1 & 5 & 18 & 18 & $75 \%$ \\
\hline & $\begin{array}{l}\text { Menghubungkan } \\
\text { gambar benda } \\
\text { dengan kata }\end{array}$ & - & 2 & 8 & 14 & 14 & $59 \%$ \\
\hline \multirow[t]{4}{*}{ Menulis } & $\begin{array}{l}\text { Mengenal simbol- } \\
\text { simbol " dapat } \\
\text { menulis huruf } \\
\text { maupun angka }\end{array}$ & - & 1 & 8 & 15 & 15 & $\begin{array}{l}62,5 \\
\%\end{array}$ \\
\hline & $\begin{array}{l}\text { Memahami } \\
\text { hubungan antara } \\
\text { bunyi dan bentuk- } \\
\text { bentuk }\end{array}$ & - & - & 9 & 15 & 15 & $\begin{array}{l}62,5 \\
\%\end{array}$ \\
\hline & $\begin{array}{l}\text { Menuliskan nama } \\
\text { Sendiri }\end{array}$ & - & 1 & 6 & 17 & 17 & $71 \%$ \\
\hline & $\begin{array}{l}\text { Menggambar } \\
\text { bebas/ } \\
\text { membuat coretan } \\
\text { gambar yang } \\
\text { bermakna }\end{array}$ & - & - & 10 & 14 & 14 & $59 \%$ \\
\hline
\end{tabular}

Berdasarkan data persentase di atas peneliti belum puas atas hasil yang di capai, kemudian peneliti mengadakan penelitian tindakan kelas kembali pada siklus kedua. 
3) Hasil pengamatan / observasi Siklus II adalah sebagai berikut :

Tabel 4

Data Hasil Pengamatan Peningkatan Kemampuan Bahasa Dengan Menggunakan Metode Membaca Dengan Media Kartu Kata Setelah Diberikan Tindakan pada Siklus II Kelas B RA Al Huda Penelupan

\begin{tabular}{|c|c|c|c|c|c|c|c|}
\hline \multirow[t]{2}{*}{ Karakteristik } & \multirow[t]{2}{*}{ Indikator } & \multicolumn{4}{|c|}{ Hasil pengamatan } & \multirow{2}{*}{$\begin{array}{l}\text { Jumlah } \\
\text { yang } \\
\text { tuntas }\end{array}$} & \multirow[t]{2}{*}{$\%$} \\
\hline & & 1 & 2 & 3 & 4 & & \\
\hline \multirow[t]{3}{*}{ Mendengar } & $\begin{array}{lr}\text { Mengerti } & \text { beberapa } \\
\text { perintah } & \text { secara } \\
\text { sederhana } & \\
\end{array}$ & - & - & 2 & 22 & 22 & $92 \%$ \\
\hline & $\begin{array}{l}\text { Mengulang kalimat } \\
\text { yang lebih komplek }\end{array}$ & - & - & 3 & 21 & 21 & 87,5 \\
\hline & $\begin{array}{l}\text { Menyebut beberapa } \\
\text { kata sifat }\end{array}$ & - & - & 3 & 21 & 21 & 87,5 \\
\hline \multirow[t]{3}{*}{ Berbicara } & $\begin{array}{l}\text { Menjawab } \\
\text { pertanyaan yang } \\
\text { lebih komplek }\end{array}$ & - & - & 3 & 21 & 21 & $\begin{array}{l}87,5 \\
\%\end{array}$ \\
\hline & $\begin{array}{l}\text { Menceritakan } \\
\text { kejadian sebab } \\
\text { akiba }\end{array}$ & - & - & 2 & 22 & 22 & $92 \%$ \\
\hline & $\begin{array}{l}\text { Menyebutkan } \\
\text { sebanyak } \\
\text { banyaknya benda } \\
\text { yang ada disekitar }\end{array}$ & - & - & 3 & 21 & 21 & $\begin{array}{l}87,5 \\
\%\end{array}$ \\
\hline \multirow[t]{4}{*}{ Membaca } & $\begin{array}{l}\text { Menyebutkan } \\
\text { simbol - simbol } \\
\text { huruf yang dikenal }\end{array}$ & - & - & 3 & 21 & 21 & $\begin{array}{l}87,5 \\
\%\end{array}$ \\
\hline & $\begin{array}{l}\text { Mengenal suku } \\
\text { huruf } \\
\text { awal dari nama } \\
\text { benda-benda yang } \\
\text { ada disekitarnya }\end{array}$ & - & - & 5 & 19 & 19 & $80 \%$ \\
\hline & $\begin{array}{l}\text { Membaca nama } \\
\text { sendiri }\end{array}$ & - & - & 4 & 20 & 20 & $84 \%$ \\
\hline & $\begin{array}{l}\text { Menghubungkan } \\
\text { gambar benda } \\
\text { dengan kata }\end{array}$ & - & - & 6 & 18 & 18 & $75 \%$ \\
\hline
\end{tabular}




\begin{tabular}{|l|l|l|l|l|l|l|l|}
\hline Menulis & $\begin{array}{l}\text { Mengenal simbol- } \\
\text { simbol " dapat } \\
\text { menulis huruf } \\
\text { maupun angka }\end{array}$ & - & - & 4 & 20 & 20 & $84 \%$ \\
\hline & $\begin{array}{l}\text { Memahami } \\
\text { hubungan antara } \\
\text { bunyi dan bentuk- } \\
\text { bentuk }\end{array}$ & - & - & 5 & 19 & 20 & $84 \%$ \\
\hline $\begin{array}{l}\text { Menuliskan nama } \\
\text { Sendiri }\end{array}$ & - & - & 3 & 21 & 21 & $\begin{array}{l}87,5 \\
\%\end{array}$ \\
\hline $\begin{array}{l}\text { Menggambar } \\
\text { bebas/ } \\
\text { membuat coretan } \\
\text { gambar yang } \\
\text { bermakna }\end{array}$ & - & - & 4 & 20 & 20 & $84 \%$ \\
\hline
\end{tabular}

Pada proses pembelajaran pada siklus II dengan kegiatan membaca dengan media kartu kata dalam upaya mengembangkan bahasa dapat diperoleh ada peningkatan, hasil belajar sudah mencapai ketuntasan belajar secara klasikal.

berdasarkan pelaksanaan kegiatan yang dilaksanakan pada siklus II ini didapatkan bahwa kemampuan anak dalam mengembangkan bahasa sudah meningkat sesuai dengan yang diharapkan.

\section{PEMBAHASAN}

Meningkatkan kemampuan bahasa melalui metode membaca dengan media kartu kata di kelompok B RA Al Huda Penulupan. Berdasarkan nilai perkembangan anak didik semester awal dan Sebelum di berikan tindakan, diketahui kemampuan bahasa anak sangat rendah, tingkat perkembangan hanya mencapai sekitar 50\%, yaitu sekitar 12 anak saja yang mempunyai kemampuan bahasa cukup baik, melihat kondisi yang demikian maka peneliti memberi pembelajaran dengan metode membaca dengan bantuan media kartu kata, maka terjadi peningkatan secara bertahap dari siklus pertama terjadi peningkatan sekitar 
75\%, yaitu sekitar 18 anak, kemudian dilakukan penelitian ulang pada siklus kedua terjadi peningkatan sekitar $85 \%$, yaitu sekitar 21 anak.

Hasil selengkapnya dapat disajikan pada tabel berikut:

Tabel 5

Data pengamatan Peningkatan Kemampuan Bahasa dengan Menggunakan Metode Membaca dengan Media Kartu Kata di Kelas B RA Al Huda Penulupan

\begin{tabular}{|l|l|l|l|}
\hline No & Siklus & Ketuntasan & Keterangan \\
\hline 1 & Kondisi awal & $50 \%$ & - \\
\hline 2 & Siklus I & $75 \%$ & Belum berhasil \\
\hline 3 & Siklus II & $85 \%$ & Sudah berhasil \\
\hline
\end{tabular}

Berdasarkan tabel di atas diketahui ada peningkatan kemampuan bahasa pada anak dilihat dari kondisi awal: 50\%, siklus I : 75\%, siklus II : 85\%, sehingga prosentase kenaikan dari prasiklus ( kondisi awal) ke siklus I adalah 25\%, dan proses kenaikan dari siklus I ke siklus II adalah 15\%. Kenaikan prosentase dari siklus I ke siklus II mengalami peningkatan 15\%.

\section{KESIMPULAN}

Penelitian tindakan kelas dengan judul "Peningkatkan Kemampuan Bahasa melalui metode membaca dengan media kartu kata pada Kelompok B RA Al Huda Penulupan” Kecamatan Pohjentrek Kabupaten Pasuruanl dilaksanakan melalui dua siklus telah menghasilkan kesimpulan sebagai berikut:

1. Perkembangan aspek menerima bahasa sebelum di beri tindakan hanya $50 \%$ yaitu sebanyak 12 anak, dengan di adakannya pembelajaran dengan metode membaca dengan bantuan media katu kata maka perkembangan bahasa 
kelompok B RA Al Huda Penulupan mengalami peningkatan, dimana peningkatan tersebut terjadi secara bertahap pada siklus pertama terjadi peningkatan sekitar 75\%, selanjutnya pada siklus kedua terjadi peningkatan sekitar mencapai 85\% atau sebanyak 21 anak dari 24 anak,

2. Anak-anak Kelompok B RA Al Huda sudah lebih mudah diajak berkomunikasi, menyampaikan pendapatnya dan mampu menerima bahasa sebagai sumber informasi melalui metode membaca dengan media kartu kata.

Berdasarkan pengamatan dari siklus I dan II dapat disimpulkan bahwa metode membaca dengan media kartu kata dapat meningkatkan kemampuan berbahasa anak didik kelompok B RA Al Huda Penulupan.

\section{DAFTAR PUSTAKA}

Adler, Mortimer J \& Van Doren,Charles (2007). How To Read a Book/Cara jitu Mencapai Puncak Tujuan Membaca. (Alih bahasa: A. Santoso dan Ajeng AP). Jakarta: PT. Indonesia Publishing.

Arikunto, Suharsini. 2008. Penelitian Tindakan Kelas Jakarta: PT. Bumi AksaraAzharArsyad. (2006). Media Pembelajaran. Jakarta: PT Raja Grafindo persada.

Alfabeta.Suharso dan Ana Retnoningsih. (2009). Kamus Besar Bahasa Indonesia. Edisi Lux. Semarang: Widya Karya.Syamsu LN. 2004, Psikologi Perkembangan Anak dan Remaja, Bandung:PT. Remaja Rosdakarya.

Depdiknas. (2007). Pedoman Pembelajaran Bidang Pengembangan Berbahasa di Taman Kanak-kanak. Jakarta: Balai Pustaka.

Depdiknas. (2002). Kamus Besar Bahasa Indonesia. Jakarta: Balai Pustaka.

Dewi, Y. A. S. (2014). Analisis Implementasi Kurikulum Tingkat Satuan Pendidikan (KTSP) di Sekolah Dasar Negeri Pisang Candi 1 Malang. Modeling, 1(2), 94-109.

Dewi, Y. A. S. (2017a). Korelasi Efektivitas Komunikasi dan Latar Belakang Etnis/Suku Orangtua Terhadap Perkembangan Bahasa Anak di Raudlatul Athfal Kabupaten Pasuruan. Seling, 3(1), 99-114.

Dewi, Y. A. S. (2017b). Metode Pembelajaran Guru Etnis Jawa- Madura Dalam Pengembangan Bahasa Siswa RA di Kabupaten Pasuruan. Seling, 3(2), 94 106.

Permendiknas. (2010). Standart Pendidikan Anak Usia Dini. Jakarta:

DepdiknasSugiyono. (2010). Metode Penelitian Pendidikan. Bandung: http//:www.instrumenPTK.com 